\title{
Endometrial expression of estrogen and progesterone receptors in non-cyclic mares treated only with long-acting progesterone
}

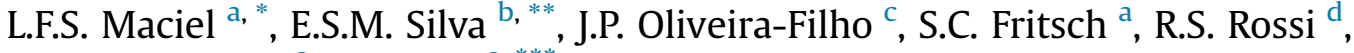 \\ J.A.C. Lourenção ${ }^{\mathrm{a}}, \mathrm{C}$. Meira ${ }^{\mathrm{a}, * *}$ \\ ${ }^{a}$ UNESP-Univ. Estadual Paulista, Campus de Botucatu, Department of Animal Reproduction and Veterinary Radiology, School of Veterinary Medicine and \\ Animal Science, Botucatu, SP, 18618970, Brazil \\ ${ }^{\mathrm{b}}$ UNITRI- Centro Universitário do Triângulo, Uberlândia, MG, 38411-106, Brazil \\ ${ }^{\mathrm{C}}$ UNESP-Univ. Estadual Paulista, Campus de Botucatu, Department of Veterinary Clinical Science, School of Veterinary Medicine and Animal Science, \\ Botucatu, SP, 18618970, Brazil \\ ${ }^{\mathrm{d}}$ UNESP- Univ. Estadual Paulista, Campus de Botucatu, Department of Veterinary Hygiene and Public Health, School of Veterinary Medicine and Animal \\ Science, Botucatu, SP, 18618970, Brazil
}

\section{A R T I C L E I N F O}

\section{Article history:}

Received 1 September 2017

Received in revised form

22 November 2017

Accepted 27 November 2017

Available online 2 December 2017

\section{Keywords:}

Equine

Anestrus

Hormonal protocols

\begin{abstract}
A B S T R A C T
Administration of progesterone (P4) after estradiol is usually performed to prepare non-cyclic mares as embryo recipients. However, there are successful pregnancy reports after embryo transfer in non-cyclic mares treated only with progestins. The objective of this study was to evaluate endometrial gene expression and immunostaining for estrogen receptor alpha (ER $\alpha)$, beta (ER $\beta)$ and progesterone receptor (PR) in seasonal anestrous mares treated with long acting P4 (LA P4). Endometrial tissue from eight seasonal anestrous mares was collected immediately before administration of $1.5 \mathrm{~g}$ of LA P4 and five days after. The receptors protein expression was evaluated by immunohistochemistry and the percentage of the immunostained area was determined by ImageJ software. Transcripts abundance for ER $\alpha$, ER $\beta$ and PR were determined by RT-qPCR. Blood samples were collected daily to measure plasma P4 concentrations. Protein expression for ER $\alpha$ was greater $(\mathrm{p}<0.05$ ) after LA P4 administration, although gene expression was not affected by treatment $(p>0.05)$. There was no difference for $\operatorname{ER} \beta$ protein expression $(p=0.07)$ and ER $\beta$ gene expression was reduced $(\mathrm{p}<0.05)$ after treatment. Gene and protein expression for PR was not altered ( $p>0.05$ ). In conclusion, endometrial PR and ER $\alpha$ expression patterns after LA P4 administration were similar to those previously found in protocols using estradiol prior to LA P4 to prepare non-cyclic mares as embryo recipients.
\end{abstract}

() 2017 Elsevier Inc. All rights reserved.

\section{Introduction}

Mares are seasonal breeders with ovulatory activity occurring during long day seasons, as spring and summer. During the winter, ovarian activity is reduced, characterizing the anovulatory season [1]. The beginning of the breeding season depends on physiological and environmental factors such as age, breed, body condition and especially photoperiod [2,3]. However, the low food availability during winter-spring transitional period in southern hemisphere

\footnotetext{
* Corresponding author.

** Corresponding author.

*** Corresponding author.

E-mail addresses: lucianafsmith@hotmail.com (L.F.S. Maciel), elisa_santanna@ yahoo.com.br (E.S.M. Silva), meira@fmvz.unesp.br (C. Meira).
}

conditions, together with the differentiated management provided to donor and recipient mares, lead to an earlier onset of cyclicity in donor mares, while recipient ones remain in anestrus [4]. Therefore, there is a limited number of cyclic recipient mares during the transitional phase.

In order to increase the offer of recipient mares in embryo transfer programs, estrogen and/or P4 treatments may be administered to non-cyclic recipient mares. In the mid 80's, studies were conducted to determine whether $\mathrm{P} 4$ alone could prepare ovariectomized mares to establish and maintain pregnancy after embryo transfer [5-7]. Three mares became pregnant out of four, receiving $300 \mathrm{mg}$ i.m. of progesterone in oil starting five days before ET [5]. The results demonstrated that the administration of estrogen was not necessary for the establishment of pregnancy in those mares. In addition, subsequent studies also reported that pregnancy was 
successfully established after treating ovariectomized recipient mares using only altrenogest [6] or progesterone in oil [7].

Because it has been demonstrated that estradiol (E2) increases the expression of $\mathrm{P} 4$ uterine receptors and that the equine embryo secretes estrogens during the early gestational phase [8], estrogen was administered prior to and together with $\mathrm{P} 4$ to ovariectomized mares, and pregnancy rates ranging from 70 to $80 \%$ were obtained within the different evaluated hormonal protocols [9]. However, it was suggested that, regardless of E2 administration, the primary requirement for pregnancy establishment and maintenance in noncyclic recipient mares was an adequate concentration of exogenous progestins [9]. Altogether, it is still not clear if estradiol is essential for preparing non-cyclic mares to become embryo recipients.

In the last years, several studies have described pregnancy rates when E2 followed by progestins are administered [4,9-12]. However, only recently the protein immunostaining and changes in abundance of transcripts for ER and PR have been studied in noncyclic mares treated with E2 followed by long acting P4 (LA P4 [13]). In cyclic mares, it is well established that messenger RNA ( $\mathrm{mRNA}$ ) and protein abundance of estrogen and $\mathrm{P} 4$ receptors in the endometrium are stimulated by E2 and down-regulated by P4 [14-16]. Loss of PR has been observed in mid to late diestrus $[13,16]$ and during early pregnancy in mares [17], and is also known to be a pre-requisite for the expression of genes for secretory proteins [18]. Nevertheless, in seasonal anestrous mares treated with $2.5 \mathrm{mg}$ of estradiol benzoate (EB), there was no apparent increase on estrogen and PR immunostaining $48 \mathrm{~h}$ after treatment [13]. Subsequently, $48 \mathrm{~h}$ after EB administration, LA P4 was administered and five days after treatment there was no apparent reduction in PR immunostaining, as observed in cyclic mares five days after ovulation [13]. Surprisingly, there was an apparent increase in ER $\alpha$ and ER $\beta$ immunostaining in the glandular epithelium five days after LA P4 administration [13].

Aiming to assess protein and transcripts abundance in the endometrium of non-cyclic mares treated only with LA P4, and to compare the results to those found in the previous study using E2 followed by LA P4, we evaluated the dynamics of estrogen and P4 receptors prior to and after LA P4 administration in seasonal anestrous mares.

\section{Material and methods}

\subsection{Animals and experimental groups}

Eight seasonal anestrous mares of different breeds, ranging from five to 15 years and weighing $350-450 \mathrm{~kg}$ were used in the study. The mares were selected based on histological evaluations of endometrial inflammation and fibrosis by biopsy [19], which only mares classified as categories I (normal endometrium) and IIA (mild inflammation and/or fibrosis) were included. During the month of June in the southern hemisphere, mares presenting ovarian follicles $<15 \mathrm{~mm}$ in diameter, absence of a CL and P4 concentration $<1 \mathrm{ng} / \mathrm{mL}$ on three evaluations at seven day intervals were characterized as anestrous mares. Once the anestrous phase was confirmed, data collection was performed, during the month of July. Mares were maintained on coast-cross hay (Cynodon dactylon) with water and trace-mineralized salt ad-libitum. Animal procedures were approved by the Ethics Committee on Animal Use of the São Paulo State University (UNESP), School of Veterinary Medicine and Animal Science, Botucatu (CEUA-100/2016).

\subsection{Hormonal treatment, blood collection and progesterone assay}

Anestrous mares were treated intramuscularly with a single dose of $1.5 \mathrm{~g}$ of LA P4 (Sincrogest Injetável ${ }^{\mathbb{R}}$, Ourofino, SP, Brazil), which was considered as day 0 (D0).

Blood samples were obtained via jugular venipuncture into heparinized tubes every $24 \mathrm{~h}$, starting immediately before P4 administration (D0) until five days after (D5). Samples were centrifuged $(900 \times \mathrm{g} / 10 \mathrm{~min})$ and plasma was harvested and stored at $-20{ }^{\circ} \mathrm{C}$ until assayed.

The concentrations of $\mathrm{P} 4$ were measured using a commercial RIA kit according to manufacturer's recommendations (RIA Progesterone, Beckman Coulter. Brea, California, USA). The antiserum for P4 assay presented low cross-reactivity to other steroid hormones, as follows: $5 \alpha$-pregnanedione (15.02\%), $5 \beta$-pregnanedione (8.12\%), 6 $\beta$-hydroxiprogesterone (5.1\%) corticosterone (4.07\%), 11desoxycorticosterone (2.56\%), 16 $\alpha$-hydroxiprogesterone (1.82\%) and $17 \alpha$-hydroxiprogesterone (1.15\%). Only one assay was performed and the intra-assay coefficient of variation was $13.4 \%$.

\subsection{Tissue collection}

Endometrial tissue samples were collected immediately before P4 treatment (D0) and on D5. Endometrial samples were recovered transcervically using an alligator jaw biopsy forceps (Botupharma, Botucatu, SP, Brazil) from the base of one of the uterine horns. Biopsies were divided in two parts and one part was frozen in liquid nitrogen and stored at $-80{ }^{\circ} \mathrm{C}$ for RT-qPCR, while the other part was fixed for $24 \mathrm{~h}$ in $10 \%$ formalin and stored at $70 \%$ alcohol for histology and immunohistochemistry (IHC).

\subsection{Immunohistochemistry}

Fixed samples were dehydrated, embedded in paraffin and cut at $4 \mu \mathrm{m}$. Paraffin sections were deparaffinized and rehydrated in serial xylene and ethanol dilutions. Antigens retrieval were performed by heating tissue sections in a pressure cooker during $30 \mathrm{~min}$ in citrate buffer solution at $\mathrm{pH} 6$. After heat treatment all slides were left to cool down for $20 \mathrm{~min}$. Endogenous peroxidases were inhibited with $8 \% \mathrm{H}_{2} \mathrm{O}_{2}$ in methanol for 20 min. Thereafter, incubation with $12 \%$ skimmed milk powder for $1 \mathrm{~h}$ at $27^{\circ} \mathrm{C}$ was performed to minimize non-specific antibody binding. Sections were incubated with antibodies previously validated for equine endometrial tissue $[13,16]$. Immunostaining was conducted with the primary antibodies $\mathrm{ER} \alpha(1: 100$, mouse monoclonal SC-311, Santa Cruz Biotechnology), PR (1:100, mouse monoclonal PR-2C5, Invitrogen) and ER $\beta$ (1:100, mouse monoclonal PPG5/10, Abcam) for $18 \mathrm{~h}$ (overnight). After $18 \mathrm{~h}$, sections were washed with dilution buffer at pH 7.4 and treated with secondary antibody (N-Histofine Simple Stain ${ }^{\circledR}$ - Nichirei Biosciences Inc.) for $30 \mathrm{~min}$ at $27^{\circ} \mathrm{C}$. Sections were washed and developed with diaminobenzidine substrate (Liquid DAB Cromogen ${ }^{\circledR}$ - Dako) for $3 \mathrm{~min}$ in room temperature. Subsequently, sections were washed and counterstained with Mayer's Hematoxylin for 90 s, washed with tap water for $5 \mathrm{~min}$, dehydrated and mounted for analysis. Negative controls were prepared using dilution buffer instead of primary antibody. A positive control was not used, since the primary antibodies used herein showed cross-reactivity to equine endometrial tissue in previous studies $[13,16]$.

\subsection{Immunostaining quantification and localization}

Objective staining intensity was performed using Image J software (WS Rasband, National Institute of Health. Bethesda, MD, USA, https://imagej.nih.gov/ij/). By using a "Threshold color" tool in the Image $\mathrm{J}$ software, it is possible to select the areas that showed brown immunostaining by DAB cromogen $[20,21]$. The selected brown immunostained areas are marked in red by the software. Thereafter, two measurements were performed: the first one 
selecting the total image, with no selection of specific regions; the second measurement was performed after the red areas were selected in order to obtain values from the immunostained area. Five slide sections of each animal within moments (D0 and D5) were evaluated for ER $\alpha, E R \beta$ and PR. In each of these evaluated images, the total area measurement and the immunostained area measurement were obtained. The mean values from the five sections were generated, and the selected area mean value was divided by the total area mean value, which result was transformed into percentage. The percentage of stained cells corresponds to the value of the immunostained area.

Images were obtained with a photomicroscope (Zeiss Axio II) using $40 \times$ magnification. Immunolocalization for ER $\alpha$, ER $\beta$ and PR in glandular and luminal epithelium, as well as in the uterine stroma, were also evaluated using the aforementioned images.

\subsection{Changes in abundance of transcripts for $E R \alpha, E R \beta$ and $P R$}

Total cellular RNA was extracted from endometrium samples using trizol (Trizol ${ }^{\circledR}$ Reagent, Life Technologies, Carlsbad, CA, USA) according to the manufacturer's recommendation. The extracted RNA was diluted in $40 \mu \mathrm{L}$ of RNase-free water. The RNA $(1 \mu \mathrm{L})$ was quantified via spectrophotometry (NanoDrop ND1000 ${ }^{\circledR}$ ) and samples with a $260 / 280$ ratio of 1.90 or greater were used for analysis. The RNA samples ( $2 \mu \mathrm{g} /$ reaction) were treated with RNase-free DNase I (Ambion ${ }^{\circledR}$, Life Technologies, Carlsbad, CA, USA) for 30 min at $37^{\circ} \mathrm{C}$, followed by treatment with DNase Inactivation Reagent (room temperature for 2 min). Quantification of RNA was performed once more by spectrophotometry and treated samples were normalized to the same final concentration of $2400 \mathrm{ng}$ using endonuclease free water. Synthesis of cDNA was performed with $2400 \mathrm{ng}$ of total RNA per $40 \mu \mathrm{L}$ of reaction using random hexamers and the High Capacity cDNA Reverse Transcription Kit (Applied Biosystems, Foster City, CA, USA).

Primers specific for estrogen receptor $\alpha$ (ESR1), estrogen receptor $\beta$ (ESR2), progesterone (PGR), glyceraldehyde-3-phosphate dehydrogenase (GAPDH), beta actin (ACTB) and beta-2microglobulin (B2M) were selected based on primers previously validated for the mare's endometrium [16,22].

Each PCR reaction was performed in duplicate, using final volume of $20 \mu \mathrm{L}$ : $2 \mu \mathrm{L}$ of $\mathrm{cDNA}, 10 \mu \mathrm{L}$ of GoTaq $^{\circledR}$ qPCR Master Mix (Promega, Madison, WI, USA), $1 \mu \mathrm{L}$ of each primer (forward and reverse) and endonuclease free water q.s.p. Quantitative PCR was completed using 7500 fast Real Time PCR systems (Applied Byosystems $s^{\mathbb{R}}$ ), with the following cycling conditions: $10 \mathrm{~min}$ at $95{ }^{\circ} \mathrm{C}$ (initial denaturation) followed by 40 cycles for $15 \mathrm{~s}$ at $95{ }^{\circ} \mathrm{C}$ (denaturation) and $1 \mathrm{~min}$ at $60^{\circ} \mathrm{C}$ (annealing/extension).

Changes in gene expression were calculated by mean quantification cycle (Cq) and then normalized for the endogenous reference gene $B 2 M$ to generate delta $\mathrm{Cq}(\Delta \mathrm{Cq})$ values, since $B 2 M$ was the most stably expressed gene in our experimental conditions as demonstrated by NormFinder software results $(\mathrm{B} 2 \mathrm{M}=0.372$; $\mathrm{BACT}=0.387 ; \mathrm{GAPDH}=0.458)$. Data were analysed in SDS 7500 v.2.05 software (Applied Byosystems ${ }^{\circledR}$ ).

\subsection{Statistical analysis}

The Wilcoxon signed-rank test was used to compare the percentage of stained cells and $\Delta C q$ values between moments (D0 and D5) for ER $\alpha, E R \beta$ and PR. Descriptive analyses were produced for the hormone concentration results (D0 $=0 \mathrm{~h}, \mathrm{D} 1=24 \mathrm{~h}, \mathrm{D} 2=48 \mathrm{~h}$, $\mathrm{D} 3=72 \mathrm{~h}, \mathrm{D} 4=96 \mathrm{~h}, \mathrm{D} 5=120 \mathrm{~h}$ ). All response variables were not normally distributed and therefore were log-transformed for analysis. A repeated measures model for non-parametric data (Friedman test) was constructed to compare P4 concentrations among collection days. Data were presented as geometric means with confidence intervals to show values in the original scale. Analyses were performed using GraphPad 5 (GraphPad Software, 2014). A P-value of 0.05 or less was considered statistically significant.

\section{Results}

\subsection{Plasma concentrations of progesterone}

Maximum concentrations of P4 were observed $24 \mathrm{~h}$ after injection of $1.5 \mathrm{~g}$ of LA P4 (D1), showing a sharp decrease on D2 after treatment, followed by a less pronounced decrease until D5 (Fig. 1).

\subsection{Receptors localization and immunoquantification}

Immunostaining for ER $\alpha$ and ER $\beta$ before (Fig. 2a and c respectively) and after treatment (Fig. 2 b and d, respectively) were mostly localized to the nucleus of luminal epithelium and glandular epithelium, and a lower staining was observed in the stroma. There was an increase $(P<0.01)$ in ER $\alpha$ staining on D5 (Fig. 3A), although no differences were observed for ER $\beta$ immunostaining after treatment $(P=0.07$; Fig. 3B). Immunolabeling for PR was detected in the stroma nuclei, luminal and glandular epithelium before and after treatment (Fig. 2e and f). There were no significant differences for PR staining before or after LA P4 administration ( $P>0.05$; Fig. $3 C)$.

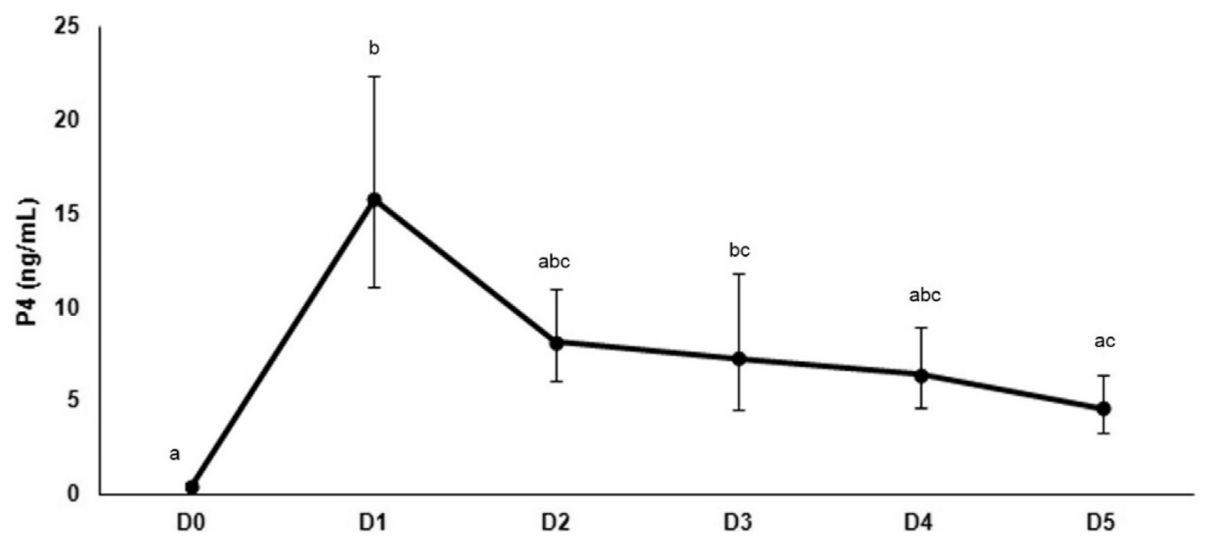

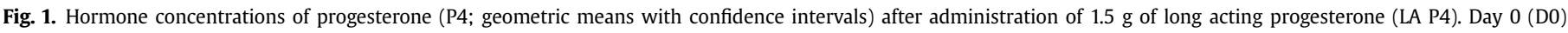
represents the moment immediately before treatment and day 5 (D5) the last day of blood sampling. Different letters indicate statistical difference $(P<0.05)$. 

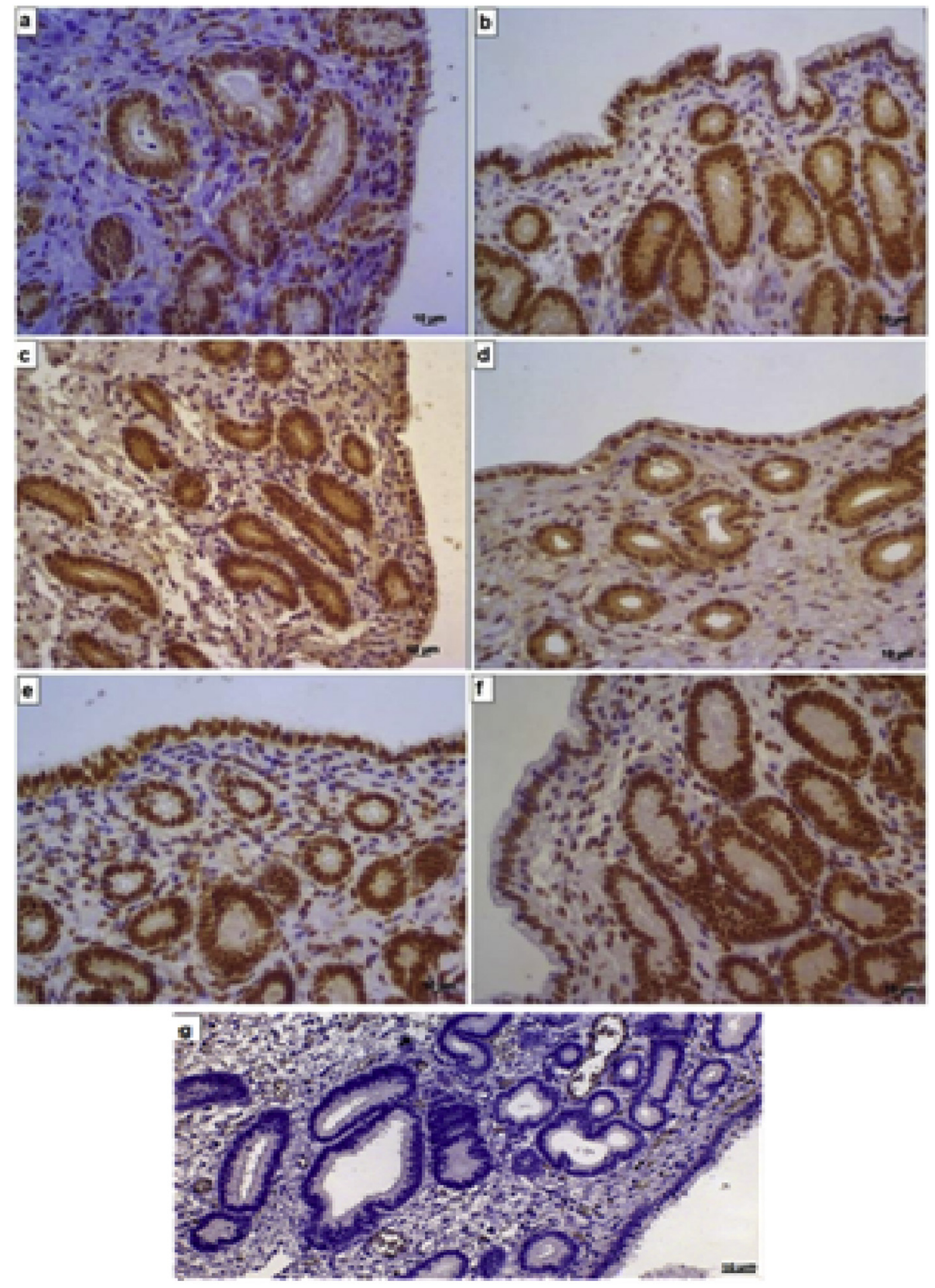

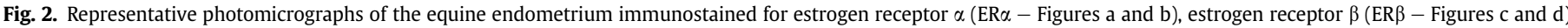

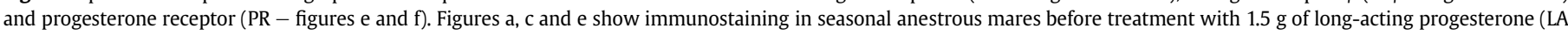
P4). Figures b, $d$ and $f$ show staining five days after treatment. Figure g indicates the negative control. Bars $=10 \mu \mathrm{m}$.

\subsection{Changes in abundance of transcripts for $E R \alpha, E R \beta$ and $P R$}

Expression of ESR2 was reduced five days after LA P4 was given $(P<0.05$; Fig. 4B). There were no differences in ESR1 (Fig. 4A) and $P G R$ (Fig. 4C) mRNA expression before and after treatment $(P>0.05)$.

\section{Discussion}

Our findings demonstrate that P4 treatment causes similar ER $\alpha$ and PR immunostaining five days after its administration when compared to protocols using E2 prior to LA P4 [13]. However, the steroid receptors immunostaining and mRNA expression showed a different pattern from what is found five days after ovulation in cycling mares [13]. Interestingly, as previously observed in noncyclic mares treated with E2 followed by LA P4, there was an increase in $\mathrm{ER} \alpha$ receptors immunostaining five days after LA P4 treatment [13].

The dose of $1.5 \mathrm{~g}$ of LA P4 was considered effective in terms of reaching the minimum concentrations required $(2.5 \mathrm{ng} / \mathrm{mL}$ [23]) for pregnancy establishment and maintenance [24,25] until day five after its administration. However, P4 profiles were different between cyclic and non-cyclic P4 treated mares. In cyclic mares, maximum concentrations of P4 are found between D6 and D8 after ovulation (12-14 ng/mL) and remain high until luteolysis [26,27]. In the present experiment, the higher P4 level was found on D1 after treatment, reaching mean values of $15 \mathrm{ng} / \mathrm{mL}$, and decreased gradually thereafter. The plasma P4 profile from day D0 until D5 
A

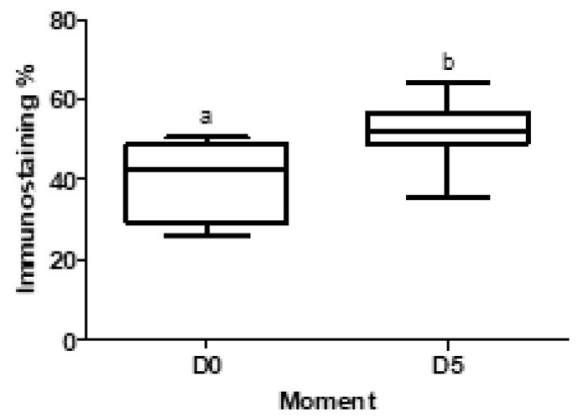

B

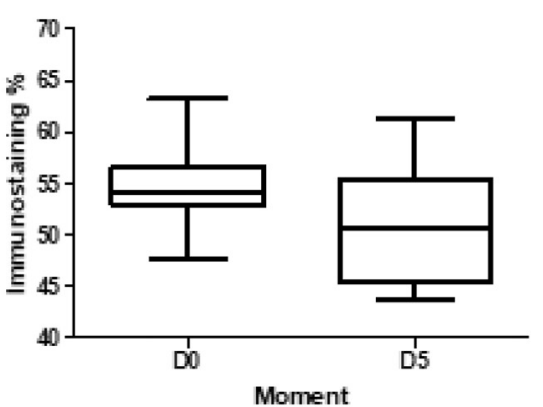

$\mathrm{C}$

PR

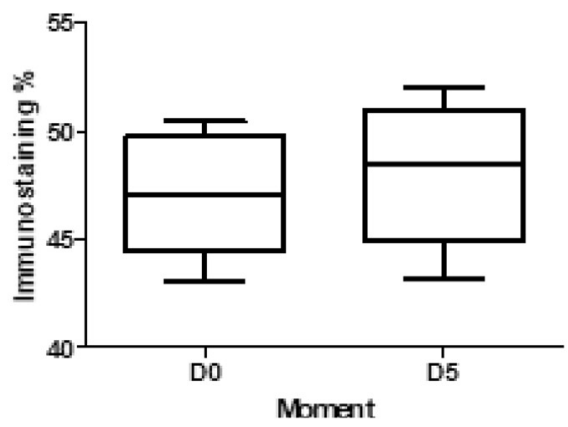

Fig. 3. Percentage of immunostaining for ER $\alpha$ (A), ER $\beta$ (B) and PR (C), before LA P4 administration (D0) and five days after treatment (D5) using Image J software. Values with different superscripts differ (a, b: $P<0.05)$.

A

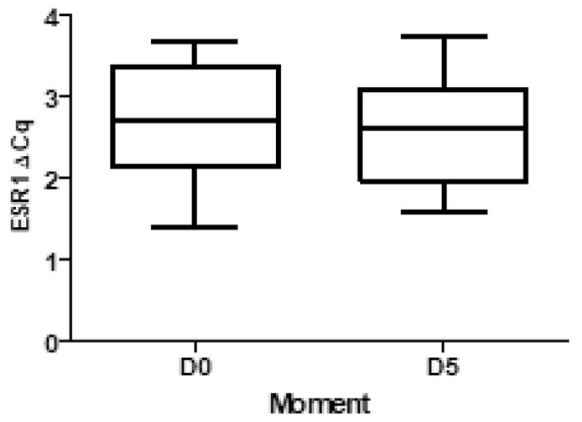

$\mathrm{C}$
B

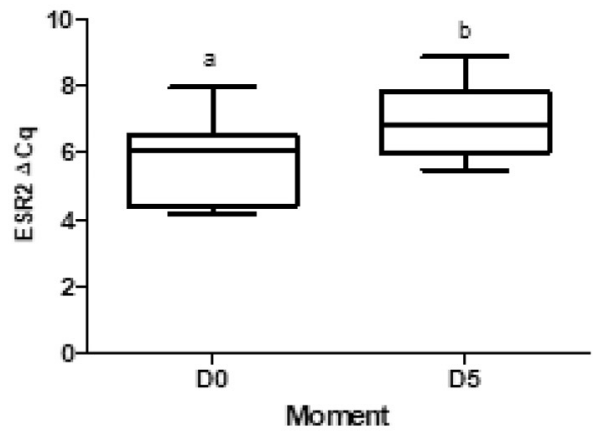

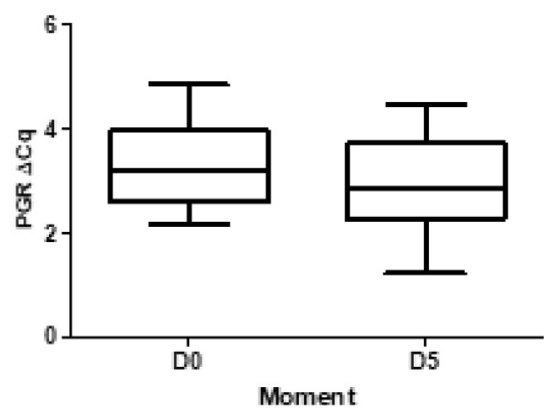

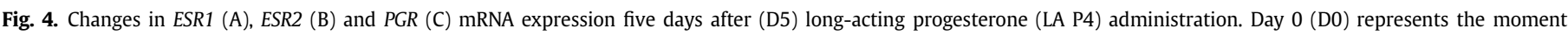

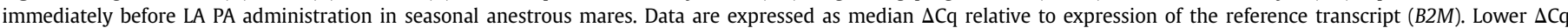
represents greater expression of the transcripts. Values with different superscripts differ $(P<0.05)$ 
after LA P4 treatment is in agreement with previous results described in non-cyclic mares also treated with $1.5 \mathrm{~g}$ of LA P4 $[25,28,29]$.

Several studies in mares have determined that both PR and ER are evident during estrus when P4 concentrations are low and estrogen concentrations are increased [14-16]. Thereafter, PR and ER both decline in mid to late diestrus, when circulating P4 levels are high $[13,16]$. Herein, such decrease of PR was not evidenced on day five after LA P4 administration, although the decrease is already observed on day five after ovulation in cyclic mares [13]. In these mares, P4 concentrations are still increasing on day five after ovulation [26,27]. In the present experiment, the higher P4 level was found on D1 after treatment and decreased gradually thereafter. Perhaps the different hormonal profile between non-cyclic P4 treated and cyclic mares could have interfered on the PR expression. Moreover, successful pregnancies after embryo transfer on D5 have been reported using this LA P4 dose [10-12]. However, additional injections of LA P4 are given, mainly after embryo transfer and pregnancy diagnosis, which may cause a further reduction on PR expression in luminal and glandular epithelium.

In late diestrus, when high circulating levels of P4 reduce PR expression, it allows an initial increase in ER expression [14-16]. In addition, when luteolysis is completed, an additional increase in ER expression is observed due to low levels of P4 and increasing levels of E2 [30]. Therefore, it is possible that the increased protein expression of ER $\alpha$ five days after LA P4 administration is due to the decrease in P4 concentrations, given the fact that the higher P4 level was found on D1 after treatment, which was reduced gradually by D5. The increased ER $\alpha$ immunostaining after P4 administration is in agreement with the findings of a recent study [13], which showed a similar P4 profile after LA P4 administration to that observed in the present study.

Estrogen beta results are controversial. No evidence for differential regulation of ER $\beta$ among cycle stages has been described in mares $[13,31]$. In the study using E2 prior to P4, ER $\beta$ protein expression appeared to be upregulated five days after LA P4 administration [13]. In the present study, ER $\beta$ mRNA expression was reduced after treatment using only P4. In humans, different patterns of protein expression for ER $\alpha$ and ER $\beta$ were observed within different tissues, as placenta, prostate, and in healthy and cancerous mammary tissue [32-34]. Although ER $\alpha$ and ER $\beta$ show structural homology, mainly on the DNA binding region, both receptors show differential mRNA and/or protein stability, leading to differential gene and protein expression of these isoforms [32].

A strong immunolabeling has been reported for ER during estrus in luminal and glandular epithelium, and a moderate to strong staining has been described in the stroma [14,15,30]. During diestrus, a decreased ER staining in the stroma has been reported [14], in agreement with our findings before and after LA P4 treatment. In non-cyclic mares treated with $2.5 \mathrm{mg}$ of EB followed by a single dose of $1.5 \mathrm{~g}$ of LA P4, an increase in ER immunolabeling was observed after LA P4 administration, mainly in the glandular epithelium cytoplasm [13]. On the other hand, in ovariectomized cows treated with P4 intravaginal device for 12 days (1.9 g P4, PRID), there was a weak ER staining in the stroma cells after treatment [35]. As for PR immunostaining, previous studies show strong immunolabeling in all endometrial cell types during estrus in cyclic mares $[13,16]$. Unlike ER staining, in the present study PR staining intensity and localization did not vary prior to and after LA P4 treatment, as observed in anestrous mares treated with estradiol followed by LA P4 [13].

It is well established that mRNA expression of ER and PR in the mare's endometrium are stimulated by estradiol and downregulated by $\mathrm{P} 4[14-16,30]$. In the present study, only ESR2 expression was downregulated by LA P4. In non-cyclic mares treated with estradiol followed by LA P4, ESR2 expression was decreased after estradiol treatment, although it was not affected by P4 administration [13]. The role of ESR2 expression is not completely elucidated, especially in the mare. In addition, ER and PR MRNA expression were not affected by P4 treatment in other species, such as ovariectomized cows [35] and sheep [36] treated with P4 intravaginal devices, in agreement with the findings of ESR1 and PGR expression after LA P4 treatment in the present study.

Cellular production rate of mRNAs may be lower than protein production. Usually a mammal cell produces two copies of mRNA/ hour, while it produces ten proteins correspondent to the mRNA at the same time interval [37,38]. Moreover, mRNAs are more unstable than proteins and can be promptly metabolized, once they show a short half-life of approximately $2.7-7 \mathrm{~h}$, while proteins have a halflife of approximately $46 \mathrm{~h}[37,38]$. These differences on mRNA and protein stability could explain the increased ER $\alpha$ protein expression after LA P4 treatment, although an increased ER $\alpha$ mRNA expression was not detected.

Furthermore, other factors may be involved in ER and PR protein and gene expression [39]. Protein expression for ER and PR were observed prior to LA P4 administration in anestrous mares in this study, as previously observed in anestrous mares [13,39] and ovariectomized cows [35]. Such finding could be due to a paracrine regulation on endometrial ER and PR [39], or perhaps to a lack of estradiol and P4 inhibition on the receptors due to the very low concentrations during the anestrous period.

In conclusion, the dose of $1.5 \mathrm{~g}$ of LA P4 was effective in terms of reaching the minimum $\mathrm{P} 4$ concentrations required for pregnancy establishment and maintenance until day five after administration. Progesterone receptors were not reduced after treatment, while $\mathrm{ER} \alpha$ were upregulated five days after LA P4 was administered, as previously observed in protocols using estradiol prior to $\mathrm{P} 4$. These results indicate that ER $\alpha$ and PR expression five days after treatment with LA P4 in seasonal anestrous mares show a similar expression dynamics to those found five days after treatment with the same dose of LA P4 in non-cyclic mares treated previously with estradiol. Additional studies are needed to elucidate ER and PR endometrial expression after estradiol and/or progesterone administration in non-cyclic mares. Moreover, studies performing embryo transfer are necessary to evaluate pregnancy rates using the $1.5 \mathrm{~g}$ of LA P4 treatment, without previous administration of estradiol.

\section{Acknowledgments}

The authors thank the CAPES (Coordenação de Aperfeiçoamento de Pessoal de Nível Superior) and FAPESP foundation (Fundação de Apoio a Pesquisa e Ensino do Estado de São Paulo, Processo Fapesp n. 2012/00298-7) for the financial support and professor Dra.Eunice Oba (UNESP-Universidade Estadual Paulista, Campus de Botucatu, Departmento de Reprodução Animal e Radiologia Veterinária) for assistance with the hormonal assays.

\section{References}

[1] Blanchard TL, Varner DD, Schumacher J, Love CC, Brinsko SP, Rigby SL. Manual of equine reproduction. $3^{\mathrm{a}}$ Ed. Mosby, Elsevier; 2003.

[2] Ginther OJ. Reproductive biology of the mare: basic and applied aspects. second ed. Cross Plains, WI: Equiservices; 1992.

[3] Nagy P, Guilllaume D, Daels P. Seasonality in mares. Animal Reproduction Sci 2000;60:245-62.

[4] Silva ESM, Frade SCF, Ignácio FS, Pantoja JCF, Puoli Filho JNP, Meira C. Supplementary corpora lutea monitoring allows progestin treatment interruption on day 70 of in non-cyclicrecipient mares. Animal Reproduction Sci 2014;144: $122-8$.

[5] Hinrichs K, Sertich PL, Cummings MR, Kenney MR. Pregnancy in 
ovariectomized mares achieved by embryo transfer. Equine Veterinary J $1985 ; 3: 74-5$

[6] Hinrichs K, Sertich PL, Kenney RM. Use of altrenogest to prepare ovariectomized mares as embryo transfer recipients. Theriogenology 1986;26:455-60.

[7] Hinrichs K, Kenney RM. Effect of timing of progesterone administration on pregnancy rate after embryo transfer in ovariectomized mares. J Reproduction Fertil Suppl 1987;35:439-43.

[8] Zavy MT, Mayer R, Vernon MW, Bazer FW, Sharp DC. An investigation of the uterine luminal environment of non-pregnant and pregnant pony mares. J Reproduction Fertil Suppl 1979;27:403-11.

[9] McKinnon AO, Squires EL, Carnevale EM, Hermenet MJ. Ovariectomized steroid-treated mares as embryo transfer recipient and as a model to study the role of progestins in pregnancy maintenance. Theriogenology 1988;29: 1055-63.

[10] Rocha Filho AN, Pessôa MA, Gioso MM, Alvarenga MA. Transfer of equine embryos into anovulatory recipients supplemented with short or long acting progesterone. Anim Reprod 2004;1:91-5.

[11] Greco GM, Burlamaqui FLG, Pinna AE, Queiroz FJR, Cunha MPS, Brandão FZ. Use of long acting progesterone to acyclic embryo recipient mares. Braz J Veterinary Res Animal Sci 2012;41:607-11.

[12] Botelho JHV, Pessoa GO, Rocha LGP, Yeste M. Hormone supplementation protocol using estradiol benzoate and long-acting progesterone is efficient in maintaining pregnancy of anovulatory recipient mares during autumn transitional phase. Animal Reproduction Sci 2015;153:39-43.

[13] Silva ESM, Ignácio FS, Fritsch SC, Zanoni DS, Pantoja JCF, Oliveira-Filho JP, et al. Administration of $2.5 \mathrm{mg}$ of estradiol followed by $1,500 \mathrm{mg}$ of progesterone to anovulatory mares promote similar uterine morphology, hormone concentrations and molecular dynamics to those observed in cyclic mares. Theriogenology 2017;97:159-69.

[14] Watson ED, Skolnik SB, Zanecosky HZ. Progesterone and estrogen recepto distribution in the endometrium of the mare. Theriogenology 1992;38: 575-80.

[15] Aupperle H, Özgen S, Schoon HA, Schoon D, Hoppen HO, Sieme H, et al. Cyclical endometrial steroid hormone receptor expression and proliferation intensity in the mare. Equine Veterinary J 2000;32:228-32.

[16] Silva ESM, Scoggin KE, Canisso IF, Troedsson MHT, Squires EL, Ball BA Expression of receptors for ovarian steroids and prostagland in E2 in the endometrium and myometrium of mares during estrus, diestrus and early pregnancy. Animal Reproduction Sci 2014;151:169-81.

[17] Wilsher S, Gower S, Allen WR. Immunohistochemical localization of progesterone and oestrogen receptors at the placental interface in mares during early pregnancy. Animal Reproduction Sci 2011;129:200-8.

[18] Spencer TE, Bazer FW. Biology of progesterone action during pregnancy recognition and maintenance of pregnancy. Front Biosci 2002;7:1879-98.

[19] Kenney RM, Doig PA. Equine endometrial biopsy. 'Current therapy in theriogenology 2'. Philadelphia: WB Saunders; 1986.

[20] Sysel AM,Valli VE, Nagle RB, Bauer JA. Immunohistochemical quantification of the vitamin B12 transport protein (TCII), cell surface receptor (TCII-R) and Ki67 in human tumor xenografts. Anticancer Res 2013;33:4203-12.

[21] Vrekoussis T, Chaniotis V, Navrozoglou I, Dousias V, Pavlakis K, Stathopoulos EM, et al. Image analysis of breast cancer immunohistochemistrystained sections using ImageJ: an RGB-based model. Anticancer Res 2009;29:4995-8.

[22] Klein C, Rutllant J, Troedsson MHT. Expression stability of putative reference genes in equine endometrial, testicular and conceptus tissues. BMC Res Notes
$2011 ; 4: 120-9$

[23] Douglas RH, Burns PJ, Hershman L. Physiological and commercial parameters for producing progeny for subfertile mares by embryo transfer. Equine Veterinary J Suppl 1985;3:111-4.

[24] Shideler RK, Squires EL, Voss JL, Eikenberry DJ, Pickett BW. Progestagen therapy of ovariectomized pregnant mares. J reproduction Fertil Suppl 1982;32:459-64.

[25] Silva ESM, Roser JF, Gomes ARC, Fritsch SC, Pantoja JCF, Oliveira-Filho JP, Meira C. Comparison of different regimens of estradiol benzoate treatments followed by long-acting progesterone to prepare noncycling mares as embryo recipients. Theriogenology 2016;86:1749-56.

[26] Ginther OJ, Utt MD, Bergfelt DR, Beg MA. Controlling interrelationships of progesterone/LH and estradiol/LH in mares. Animal Reproduction Sci 2006; 95:144-50.

[27] Ginther OJ, Gastal EL, Gastal MO, Utt MD, Beg MA. Luteal blood flow and progesterone production in mares. Animal Reproduction Sci 2007:99:213-20.

[28] Bringel BA, Jacob JCF, Zimmerman M, Alvarenga MA, Douglas RH. Biorelease progesterone LA 150 and its application to overcome effects of premature luteolysis on progesterone levels in mares. Rev Bras Reprodução Anim 2003;27:498-500.

[29] Burns PJ, Morrow C, Abraham J. Evaluation of biorelease P4 LA 300 in the mare. In: Proceedings of the 7 th international symposium on equine embryo transfer. UK: Cambridge; 2008. p. 82-3.

[30] Hartt LS, Carling SJ, Joyce MM, Johnson GA, Vanderwall DK, Ott TL. Temporal and spatial associations of oestrogen receptor alpha and progesterone receptor in the endometrium of cyclic and early pregnant mares. Reproduction 2005; $130: 241-50$.

[31] Pinto CRF. Progestagens and progesterone. Equine reproduction. second ed.. Blackwell Publishing.

[32] Scobie GA, Macpherson S, Millar MR, Groome NP, Romana PG, Saunders PTK Human oestrogen receptors: differential expression of ERalpha and beta and the identification of ERbeta variants. Steroids 2002;67:985-92.

[33] Pelletier G, El-Alfy M. Immunocytochemical localization of estrogen receptors $\alpha$ and $\beta$ in the human reproductive organs. I Clin Endocrinol Metabolism 2000;85:4835-40.

[34] Royuela M, Miguel MP, Bethencourt FR, Sánchez-Chapado M, Fraile B, Arenas MI, et al. Estrogen receptors and in the normal, hyperplastic and carcinomatous human prostate. J Endocrinol 2001;168:447-54.

[35] Kimmins S, MacLaren LA. Oestrous cycle and pregnancy effects on the distribution of oestrogen and progesterone receptors in bovine endometrium. Placenta 2001;22:742-8.

[36] Wu WX, Owiny J, Zhang Q Ma XH, Nathanielsz PW. Regulation of the estrogen receptor and its messenger ribonucleic acid in the ovariectomized sheep myometrium and endometrium: the role of estradiol and progesterone. Biol Reproduction 1996;55:762-8.

[37] Schwanhäusser B, Busse D, Li N, Dittmar G, Schuchhardt J, Wolf J, et al. Global quantification of mammalian gene expression control. Nature 2011;473: 337-42.

[38] Vogel C, Marcotte EM. Insights into the regulation of protein abundance from proteomic and transcriptomic analyses. Nat Rev Genet 2013;13:227-32.

[39] McDowell KJ, Adams MH, Adam CY, Simpson KS. Changes in equine endometrial oestrogen receptor $\alpha$ and progesterone receptor mRNAs during the oestrous cycle, early pregnancy and after treatment with exogenous steroids. J Reproduction Fertil 1999;117:135-42. 